Portland State University

PDXScholar

\title{
How women are made: a look at the issues of the women's liberation movement
}

Lenore Jan Coffey

Portland State University

Follow this and additional works at: https://pdxscholar.library.pdx.edu/open_access_etds

Part of the Gender and Sexuality Commons, Inequality and Stratification Commons, and the Social Psychology and Interaction Commons Let us know how access to this document benefits you.

\section{Recommended Citation}

Coffey, Lenore Jan, "How women are made: a look at the issues of the women's liberation movement" (1971). Dissertations and Theses. Paper 1450.

https://doi.org/10.15760/etd.1449

This Thesis is brought to you for free and open access. It has been accepted for inclusion in Dissertations and Theses by an authorized administrator of PDXScholar. Please contact us if we can make this document more accessible: pdxscholar@pdx.edu. 


\title{
"How Women Are Made: A Look At The Issues of The Women's Liberation Movement"
}

\author{
by \\ Lenore Jan Coffey
}

\author{
Submitted in partial fulfillment of the \\ requil rements for the degree of \\ MASTER OF SOCIAL WORK \\ Portland State University \\ School of Soclal Work
}


Th1s Description Includes:

\author{
Background \\ Methodology \\ and of this project \\ Rationale \\ Statement of Personal Position \\ Syllabus \\ Workshop Plan \\ Seminar Reading List \\ Blbllography
}




\section{Background}

This project was orfginally concelved of as an exploration and written presentation of varfous dimensions of the contemporary social movement called the Women's Liberation Movement. The exploration was to be through personal experience in the movement and research in movement ifterature.

I became aware of the Women's Liberation Movement, which was just gaining momentum, in 1969, through a serfes of articles appearing in Portland's "underground" newspaper, The W1llamette Bridge and then through new feminist 11terature which I began to acquire.

I reread classics: Betty Friedan's The Feminine Mystique which had appeared in the early nineteen sixties and S1mone de Beauvolr's exhaust1ve work on woman, The Second Sex.

The research project seemed to me to be a vehfcle whereby I might explore a soctal movement which had a strong personal appeal to me and one with which I strongly Identifled. I decided to call my project "Dimensions of Women's Liberation".

From a research polnt of view, the speciflc objective was to Identify the Issues and elements of the Women's Liberation experience for those who are Involved, in other words, to determine what are the salient dimensions of this experience for the Individual in Women's Liberation. 


\section{Methodology}

Unt11 the fall of 1970 , and the beginning of my second year In graduate school, my Involvement with the movement was confined to reading and discussion and argument with other people, part1cularly classmates. I knew that local sympathizers with the movement were attempting to organize in Portland and were following a format established in many areas throughout the country, wh1ch consists of some sort of central organization with the base of the movement being small groups or "consclousness-ratsing groups". Small groups were belng organtzed on a geographical basis In Portland.

With the decision to formalize ay inquiry into Women's Liberation, I Joined a new group in southeast Portland whlch met weekly at the home of one of Its members. A Women's Center - a large rented house - was just being established, and I began to attend the "structure meetings" or organizational meetings there which had previously been held at Centenary W11bur Methodist Church.

I subscribed to Women: A Journal of Liberation and regularly purchased Women's Liberation newspapers which are published in several major cltles throughout the country. These have such colorful titles It Aln't Me, Babe from the song of the same title by Bob Dylan, Off Our Backs, 
Everywoman, and Aln't I A Woman? from Sojourner Truth's often-quoted (1n new femln1st literature) speech before the Women's Rights Convention at Akron, Oh10, in 1851.

I continued to acquire books, magazines, pamphlets, and b1bllographles from the growing body of new feminist 11terature and examined articles and features appearing in most of the we11-known magaz1nes: T1me, Look, Newsweek, Harper's, and Atlant1c Monthly. Some speclallzed magazines such as Transaction did many-page features on women, and New Left and Radical publications such as Leviathan from the Bay Area and the new Radical Therap1st devoted whole 1ssues to women from a new feminlst perspective.

I attended lectures and remained alert to spectal media coverage of Women's Liberation.

As I studied, 11stened, watched, and particlpated, two things became apparent to me: I reallzed that there was 11ttle that I could say in a written product about the vital 1ssues of the Women's Liberation Movement that wouldn't be simply restating what had already been sald. I also realized that my participation in the movement not only Influenced my personal growth and the way in which I vlewed myself and my $11 \mathrm{fe}$, but also profoundly influenced my perspective on the formation, growth, and development of female human behavior as well as heightening my awareness of, apprectation for, and concern with the socto-economic environment with which the Individual interacts. A11 of 
which soclal workers - at least theoretically - are vitally concerned.

Consequently, I began to want to share what I'd learned In a more organized and less casual fashion with other social work students. When Dr. Art Emlen, my research advisor, suggested that my profect culminate in some sort of workshop or seminar serles, I eagerly agreed. I determined to plan a course whlch would offer students the opportunity to examine 11terature, 11sten to guest speakers, exchange Ideas with each other, and decide for themselves whether the Women's Liberation Movement has Implications for them - as it has for me - as soclal work practicioners, and 1f $\mathrm{so}$, what is the nature of those Implications.

The objectives for the workshop and seminar are discussed in the attached syllabus and course plan. An evaluation of the course w111 be forthcoming at the end of spring term when the course terminates.

During course preparation I consulted many times wth Dr. Emlen; I also met with John Longres and frequently consulted with Diane Pancoast who also happened to be my fleld instructor and who agreed to go on record as official Instructor for the course, although I w11 actually teach the course. The Women's Liberation small group to which I belonged shared in my plans, offered 1deas and suggestions, 
and several members agreed to participate as speakers in the workshop and subsequent seminars.

Rat1onale For The Course - Issues of Women's LIberation

I would like to defend my stance that the lssues with which Women's Liberation is concerned are or should be 1ssues with wh1ch soc1al workers are concerned. I'11 discuss 1ssues of the movement from the point of view of "Why Women's Liberation?" an article by Marlene Dixon, who is professor of soctology at McGill University. The art1cle f1rst appeared in the December, 1969, 1ssue of Ramparts Magazine and has been reprinted in pamphlet form by the Bay Area Radical Education Profect, (941 Guerrero St., San Francisco, Callforn1a, 94110).

Each student who registers for the course will be given a copy of this pamphlet at registration and will be asked to read it before coming to the workshop and four subsequent seminars.

Marlene D1xon refers to the 1960's as "a decade of 11beration" and says that women have been swept up by the drive toward 11beration along with Blacks, Chicanos, Indians, and poor whites - all those who are discovering the nature of their oppression in American soclety and who have become aware that they could live more free and fully human lives. 
In less than four years a varlety of women's groups have come Into existence which range from such middle-class, reform-minded groups as the nationally-based National Organization for Women (NOW) to 1ocal, radical, revolutionminded feminist groups in every major city in the country. There are women's caucuses within nearly all New Left groups and in most professional associations in the soctal sciences.

In 1968, according to Dixon, the movement was focused upon male chauvinism and the psychological oppression of women. However, the emphasis is currently on understanding the social and economlc bases for oppression of women and the frameworks for analysis range from democracy to Marxism. But even more striking to Dixon than this shift in emphasis 1s the loss of fear in women. Women are daring to strive toward becoming complete human beings, daring to look for alternatives to the $11 \mathrm{mlted}$ and $11 \mathrm{mlting}$ role which our soclety assigns them, and are no longer afrald of losing their very identities as women.

The early women's movement, which embraced almost a hundred years, came to an end In the 1920's. In the thirties and fortles women were forced into the labor market by hard times and the war, and with the end of the war, they were forced out again. Dixon puts it this way: 
The story has been repeated after each war and the reason is clear: women form a flexible, cheap labor pool which is essential to a capitalist system. When labor is scarce, they are forced onto the labor market. When labor is plentiful they are forced out. Women and blacks have provided a reserve army of unemployed workers, benefiting capitalists and the stable male white working class allke. Yet the system Imposes untold suffering on the victims, blacks and women, through low wages and chronic unemployment. (p. 2)

In the fiftleg the average age at marriage declined, the size of famllies went up and the migration to the suburbs began. Women were expected to live happlly and devotedly focused on husband, home, and chlldren.

By the end of the fiftles, there were three signiflcant social developments which provided the basis for a rebirth of the women's movement. By the end of the fifties, women made up one-third of the labor force. For the most part, they were In low-paying service, clerical, and semi-skilled fobs for which they were pald less than men for doing Identical work.

Second, love and marriage in suburbla were not turning out to be the foyous, fulfilling experience for countless women that they were supposed to be.

Third, the growing civil rights movement, which was later to become the New Left, was attracting thousands of young people, and with their eventual disillustonment 
In the face of harsh, political reallty came the breakdown of sex mores and roles along with the questioning and refection of traditional political 1dealogies and cultural myths. Even In organizations such as Students For A Democratic Soclety there was tremendous disillusionment on the part of radical women who expected to work side by side with male radicals for what they envisioned as a truly democratic soclety, but found Instead that they were expected to make coffee and keep the beds warm.

The three mafor groups of women, then, that make up the new women's movement, according to Dixon, are working women, mlddle class women, and students.

Understandably, working women are most concerned with quaranteed employment, fust wages, job discrimination, and certainly, child care. Dixon states that their oppression Is rooted in industrial capitalism and an exploitive labor market.

Middle class women are partlcularly aware of the dehumanizing effect of sertously $11 \mathrm{mited} 11 \mathrm{ves,}$, and know the consequences of Imposed Inferiority and "psychological mutilation and infustice of institutionalized segregation," and the lack of gratification in trying to live vicariously through husband and chlldren. 
Students, as unmarried, middle class girls, are most sensitized to the sexual exploitation of women and rebel against the expectations of passive and dependent behavior In relationships. They also refect the 1dea that they must function as sexual objects, belng defined in primarlly sexual rather than human terms, and belng pressured to package themselves as attractive merchandise on the sex market.

Dixon Insists that all women suffer from economic exploftation, from psychological deprivation, and from exploftive sexuality.

She goes on to say that $1 t^{\prime}$ s necessary to destroy the Ideology of male supremacy wh1ch bastcally Insists upon the blologlcal and soctal Infertortty of women, which is the same - not simflar, but same - sterotyping that kept blacks In thelr place for so long. She polnts out that many women belleve that they are, In fact, Inferfor, and that this Is one of the ways in which oppressed people contribute to their oppression.

She points out that the Image of woman in this culture Is for the most part empty and degrading and hardly encourages taking women seriously as human belngs. She states that studies Indicate that black acceptance of white sterotypes fostered mut1lated 1dent1ty, allenation, rage, and selfhatred, and that thls certalnly occurs among women, also. 
Women are notorious for not liking other women and for not liking to be Identified with other women.

Marlene Dixon points to marriage as being the chief vehicle for the oppression of women. It is perhaps, however, more advantageous to be a drudge in one's own kitchen than a drudge in a factory or office. Also, along with marriage goes improved social status for many women, since women are usually defined by the men they attach themselves to and by their children.

Women do a great economic service for the society. There are 44 million housewives of all ethnics groups, classes, and races. They are provlding essential services and labor - free. Since housework is outs1de of the market place and the world of trade, and since salary often mirrors the value of different kinds of work in this society, women's work has very low status. So do women.

Women are not only free laborers but do another service for the economy as consumers. And then there are the women who work as wage-earners and return home to prepare dinner, clean house, etc. and properly fulfill the requirements of their womanly role.

Sixty-two per cent of women working in 1967 were doing so out of economic need, and the trend is clearly 
toward greater numbers of women entering the work force. Dixon provides some Impressive statistics which I'll not c1te here.

The popular 1dea of a Black Amertcan matrlarchy 1s unfounded, accord1ng to D1xon. She states that black women haven't been the oppressors of their men because rac1sm and economic explottation come from the white world. In fact, Black women are the most discriminated against in terms of opportunity. In 1960,44 per cent of marrled Black women with children under six years were working. To begin to compete in the labor force, education is necessary; the bulk of illiterate women are Black. In this society, Black women carry a heavy social and economic burden, with two strikes against them: color and sex.

Dixon also states that the Image of the "pampered middle class woman" is incorrect and naive, and that middle class women, widowed, divorced, or with nothing to occupy them at home return to the labor market to find themselves forced into working class 11fe in low-pald, unskilled or semi-skilled work.

She insists that nothing short of radical social change w111 improve the social position of women; since my purpose here is to outline the 1ssues with which Women's Liberation is concerned from the perspective (a common perspective among 
movement women, I belleve) of an activist woman in the movement, I'11 not discuss reform or revolution.

Th1s is one of the concluding paragraphs of Marlene D1xon's essay:

The heart of the movement, as in all freedom movements, rests in women's knowledge, whether articulated or st111 only an 111 ness without a name, that they are not inferior - not chicks, nor bunnies, or quall, nor cows, nor bitches, nor ass, nor meat. Women hear the 11tany of their own dehumanization each day. Yet all the same, women know that male supremacy is a Ile. They know they are not animals or sexual objects or commodities. They know their lives are mutilated, because they see within themselves a promlse of creativity and personal integration. Feeling the contradiction between the essentially creative and self-actualizing human being within her, and the cruel and degrading less-than-human role she 18 compelled to play, a woman begins to percelve the falseness of what her soclety has forced her to be. And once she perceives this, she knows she must fight. (p. 14)

The 1ssues of Women's Liberation are freedom from economic, social, and sexual exploitation; freedom from employment discrimination, and Increased opportunity for self-actualization. Increased opportunity for selfactualization is present with greater freedom in the areas mentioned; it is also potentially a significant part of the Individual's experience In the Women's Liberation Movement. 
A woman who becomes Involved in the movement has the opportunity to meet with other women on a non-competetive basis to discuss, analyze, and take action on the 1ssues.

In this process a woman learns that her "problem" is not a solitary and neurotic unwillingness to be a woman, but rather that she shares in a widespread unwillingness to accept the societal definftion of what a woman is and does. This is a "liberating" awareness for a woman, and this awareness--combined with friendship and support from other women, and mutual efforts toward personal growth and development and effecting change in soclety's treatment of women-fosters greater self-acceptance and increased self-esteem In the Individual woman. Her desire for unique and Individual self-actualization is called to her attention and legitimlzed, then, by the Women's Liberation Movement, and the movement becomes, in part, a vehicle through which some of this selfactualization can be accomplished.

Obviously the issues of Women's Liberation are - broadly speaking - 1ssues with which social workers in their professional roles are familiar. The Women's Ltberation Movement In America relates to these Issues as they apply to the position and plight of women in this country. 


\section{Personal Position}

My personal position is this: The Women's Liberation Movement has something to say to social workers who purport to be concerned with the individual's relationship to his or her environment, his or her self-actualization and mental health, and the Individual's use and enfoyment of his or her human potential.

The course which I'm offering is an opportunity for soclal work students to learn that Women's Liberation is not about burning brassiers or acquiring penises, but about human belngs who are tired and sick and furlous over the waste of their humanness in the name of their child-bearing faculty, or in the name of any other reason, no matter how sugar-coated or romantic or mystical, which claims "differences" between the sexes and manages to keep woman eternally at the service of someone or something.

Anyone who doubts this should consider the enormous threat Inherent in the Women's Liberation Movement to many people. The fact that Women's Liberation women who were demonstrating at the Untversity of North Carolina were urinated on by male hecklers probably says more about the position of women in this soclety than a ton of rhetoric. Why is this movement so threatening? The entire course could be bullt upon that question. 
Courge Title: "How Women Are Made: A Look At The Issues of The Women's Liberation Movement."

Course Number: 507 - To be offered to f1rst and secondyear students, Spring Term, 1971.

Instructor: Offlclal Instructor, Dlane Pancoast. Actual Instructor, Lee Coffey.

Cred1t: Two hours.

Course requires meeting initially for one full day for a workshop and subsequently meeting for four, two-hour seminars, one every other week.

Object1ves :

1. To stimulate soctal work students to examine a current, vital soctal movement from a soctal work point of view and become aware of and begin to deal with the Implications of this movement for the soclal work practicloner.

"Social work point of view" refers to the professional point of view and frame of reference of the Individual student soclal worker. A student in this class might declde that this movement has no soclal "1mplications" at all or that the Implications are horrifying and as a "soclal work practicloner" he might make an effort to see that a11 women In Women's LIb are institutionalized. (He or she would be meeting the first objective of the course, although not in a way which is compatible with the instructor's bias.)

2. To examine from varlous perspectives some currently taken-for-granted 1deas about "Inherent" sexual character1st1cs, sexual 1dentity, and sexual roles of women (and Inevitably, men); to encourage thinking about these things In new ways, personally and professionally, and to creatively discuss the feastbility and Implications of changes in these 1deas. 
For example: Most of us grow up belleving that all women should be mothers, that women "need" to be mothers. It Is now belng argued that women don't "need" to be mothers any more than someone with vocal chords "needs" to sing. How do you (student) react to that statement? How w11l your 1deas on women and motherhood affect your practice with female clients? What would be some of the social Implications of wide acceptance of the 1dea that bearing children is one of many opportunitieg avallable to women and not necessar1ly better than others?

3. To provide an opportunity for personal growth.

Nearly all of us are blologically male or female and most of us maintain an 1dentity - at least soclally.as a man or a woman. A11 of us are affected by socletal definitions of what is appropriate to being women and men. Students in this class will have the opportunity to critically examine some of these definitions and prescribed behavior, as well as their own attitudes and sterotypes and evaluate them on the basis of proven validity, humanness, and usefullness, and they might find that such an evaluation and the conclusions drawn therefrom result in useful insight in their personal 11ves.

Content And Teaching Method

The course will begin with a full-day workshop; all students registering for the course will be given a pamphlet copy of "Why Women's Liberation?" by Marlene Dixon and will be asked to read it before coming to the workshop. Workshop content has been selected to inform students of the key lssues of Women's Liberation, to provide information about the movement 1 tself, and to give students the opportunity to talk with women who are active in the movement.

Each subsequent seminar w111 focus upon a specific toplc or toplcs to which students can relate personally as well as professionally. Relevant readings will be assigned each time, and occasionally outside resource persons will be Invited to address the group and participate in discussions. 
The readings for the first seminar, entitled "What Makes a Woman?" present intelligent and entertaining analyses of the current female situation from a feminist point of view.

In this first seminar, studente will be encouraged to react to the workshop and to exchange information about their reasons for signing up for this course, their views on Women's Liberation and relevant Issues, and how they relate any of this to themselves as soclal workers.

The second seminar, "Women And Work - Alternatives To The Exlsting Division of Labor", focuses upon women in the labor force, division of labor between the sexes, and consideration of alternatives which might mean a more equitable sharing of responsibility for child care, housework, etc. The readings primarily discuss the experiences of women who are wage earners in various occupations.

The guest speaker will be a woman who w111 discuss the realitles of working in a man's world.

"Sex", the third seminar, revolves around readings which are concerned with sex differences, sexusl relations, sexual identity, behavior which is considered sexually deviant, and sexual exploitation of women. The relationship between Gay Liberation and Women's Liberation will be discussed. Guest speakers will be from Gay Liberation.

The reading material for the fourth seminar, which is ent1tled "Women's Liberation And Social Workers", deals with minority women in Women's Liberation, women on Welfare, women in psychoterapy, and women in revolution and social change; in other words, women in areas in which social workers are theoretically at home.

The guest speaker, Diane Pancoast, w111 discuss Women's Liberation and social work, and class discussion will address 1tself to relating the material in the course to the students as social workers. 
Seminars w111 be designed for minimum lecture, maximum discussion. The texts for seminars will be Slsterhood Is Powerful: An Anthology of Writings From The Women's Liberation Movement, edited by Robln Morgan (Vintage - \$2.45) and Notes From the Second Year: Women's Liberation, Major Writings of the Radical Feminists, edited by Shulamith Firestone $(\$ 1.50)$. Other readings wi11 be in the form of handouts.

Some of the Ideas expressed in the readings - most of which are written from a radical polnt of view - might Impress some students as extreme, shocking, of fensive, "sick", and one-sided. The point, however - to emphasize it again - is to:

1. examine the $s i g n i f i c a n c e$ of the fact that these ldeas are being discussed at all,

2. discuss the validity of these 1deas and points of view, and

3. determine how or if they might be used in a creative fashion by the individual, personally and professionally.

\section{Course Requirements}

1. Participate in workshop and complete questionnalre.

2. Attend seminars, do readings, and particlpate in discussions.

3. Complete final written assignment which will consist of an evaluation of the course on the basis of the stated objectives and a subjective statement by the student reflecting how he or she met the objectives of the course. 


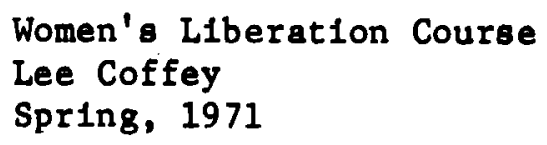

\section{WORKSHOP}

Workshop: "How Women Are Made"

When: April 5, 1971.

Where: Room 5 (downstairs), Soclal Work I

Agenda:

1. All students complete questionnalre.

2. Get coffee and donuts and view material posted on walls.

3. Presentation by women In Portland Women's Liberation:
a) "Why Women's Liberation?"
b) "Freud and H1s Friends"
c) "Women and Employment"
d) "Social and Economic Roots of Women's Oppression"

Question and answer period after each presentation.

4. LUNCH - There w111 be a 11terature table where WLM literature w1ll be avallable during lunch hour.

5. Demonstration of Self-Defense Techniques.

6. Presentation: "The Movement: How It's Organized"

7. Handout: "What It Would Be L1ke If Women W1n" - Gloria Ste1nem. (T1me essay, August 31, 1970)

8. Break to get coffee and read essay. 
9. Divide Into small groups. Groups will be asked to reflect upon and discuss materlal presented during the day and come up with three questions which can be discussed by a panel of $81 x$ volunteers when large group reconvenes. Panel w11l consist of three students who are pro Women's LIb and three againgt.

10. Reconvene. Questions from groups written on board and checked for duplications. Students volunteer for panel.

11. Pane1.

12. Students complete comment and question sheet to be used in further planning seminars.

13. Handouts: Schedule and reading 118 tor seminars. 
Women's Liberation Course Lee Coffey

Spring, 1971

REQQUIRED READING FOR SEMINARS

Texts: S1sterhood Is Powerful: An Anthology of Writings From the Women's Liberation Movement. Robin Morgan, Editor.

Notes From The Second Year: Women's Liberation. Major Writings of the Radical Feminists. Shulamith Firestone, Editor.

These books have been ordered through the PSU bookstore.

1st seminar - What Makes a Woman?

$4 / 19 / 71$

"You've Come A Long Way, Babyl Historial Perspectives"

Connie Brown and June Seitz ...... Sisterhood, p.3

"A Psychiatrist's View: Images of Women -

Past and Present, Overt and Obscured."

Natalie Shainess, M.D. ......... Sisterhood, p. 230

"Barbarous R1tuals" ..................... Sisterhood, p. 161

" 'Kinder, Kuche, Kirche' As Scientific Law,

Psychology Constructs the Female"

Naomi Weisste1n ............. S1sterhood, p. 205

"Woman And Her Mind: The Story of Everyday Life"

Meredith $\operatorname{Tax} \ldots \ldots \ldots \ldots \ldots$ Notes, $p . \ldots$ 
REQUIRED READINGS, continued.

"John And Mary: The Laugh's On Us"
\[ \text { Verna Tomasson ............. HANDOUT } \]

"Love"

Shulamith Firestone .......... Notes, p. 16

"Know Your Enemy: A Sampling of

Sexist Quotes" ......................... Slsterhood, p. 31

2nd seminar - Women And Work - Alternatives To Existing

5/3/71 Division of Labor

"Sesame Street and Sex-Role Sterotypes"
Jo Ann Gardner .............. HANDOUT

"The Politics of Housework"

Pat Ma1nard1 .............. Notes, p. 28

Selected Readings ..................... Sisterhood pp. $37-101$

"What It Would Be Like If Women Win"

Gloria Steinem ............. Time essay

31 August 1970

GUEST SPEAKER

3rd seminar - Sex

$5 / 17 / 71$

"Primate Studies And Sex Differences"

Sally Linton .............. HANDOUT 
REQUIRED READINGS, continued.

"The Myth of Vaginal Orgasm"

Anne Koedt ................ Notes, p. 37

"We Like To Find A Late-Maturing Gir1:

The Playmate Process"

Thomas Meehan $\ldots \ldots \ldots \ldots \ldots \ldots$ HANDOUT

"The Hooker"

Ellen Strong ................ S1sterhood, p. 289

"Perspectives on Lesbianism:

Lesbians as Bogeywomen"

Judy Grahn ............... HArdDOUT

"Wotes of A Radical Lesbian"

Martha Shelly ............... S1sterhood, p. 306

GUEST SPEAKERS

4th seminar - Women's Liberation And Soc1al Workers

$5 / 31 / 71$

"False Consclousness"

Jennifer Gardner .............. Notes, p. 82

"Women And The Welfare System"

Carol Glassman .............. Slaterhood, p. 102

"Women In The Black L1beration Movement:

Three Views"

Sisterhood, pp. $340-361$ 
REQUIRED READINGS, continued.

"Colonfzed Women: The Ch1cana" ............. S1sterhood, pp. $376-384$

"Female Liberation As The Basis For Soclal Revolution"

Roxanne Dunbar ............... Notes, p. 48

"Open Letter To Paychiatristo"

Nicole Anthony .............. HANDOUT

"Marrlage And Poychotherapy"

Phyl11s Chesler ............. HANDOUT

GUEST

TAKE-HOME EVALUATION OF COURSE 
$\underline{\text { Books }}$

de Beauvo1r, S1mone. The Second Sex. New York: Bantam Books, 1961. First Printing: France, 1949.

B1rd, Caroline. Born Female. New York: Pocket Books, 1969. F1rst Printing: David McKay Edition, June, 1968.

Ch11de, Gordon. What Happened In H1story. Baltimore: Penguin Books, 1942.

Friedan, Betty. The Feminine Myot1que. New York: De11 Publishing Company, Inc., 1965.

M1let, Kate. Sexual Polit1cs. Garden C1ty, New York: Doubleday and Company, Inc., 1970.

Morgan, Robin. Editor. S1sterhood Is Powerful. New York: V1ntage Books, 1970.

Scott-Maxwe11, Flor1da. Women And Somet1meg Men. New York and Evanston: Harper and Row, 1971. F1rst Printing: Alfred A. Knopf, Inc., 1957.

Stambler, Sookle. Compller. Women's Liberation: Blueprint For The Future. New York: Ace Books, 1970.

Tyler, Allce Felt. Freedom's Ferment. New York: Harper and Row, 1962. F1rst Printing: University of Minnesota Press, 1944.

Ware, Celestine. Woman Power: The Movement For Women's L1beration. New York: Tower Publ1cations, Inc., 1970. 
Sources Consulted, continued.

\section{Pamphlets}

Breitbart, V1ck1. Day Care, Who Cares? Radical Education Profect, Box 561-A, Detro1t, Mlchigan, 48232. No date.

Densmore, Dana. Sex Roles And Female Oppress1on. New England Free Press, 791 Tremont St., Boston, Massachuset ts, 02118. No date.

D1xon, Marlene. Why Women's Liberation? Bay Area Rad1cal Education Profect, 941 Guerrero St., San Francisco, Callfornia, 94110. F1rst published In Ramparts, 1969.

Gordon, LInda. Families. Co-published: Bread and Rosses, 1145 Massachusetts Ave., Cambridge, Massachusetts, 02139, and New England Free Press, 961 Tremont St., Boston, Massachusett8, $02118,1970$.

Mitchell, Jullet. Women: The Longest Revolution. Bay Area Radical Education Profect, 491 Guerrero St., San Franc1sco, Cal1fornia, 94110 . No date.

McAfee, Kathy. Wood, Myrna. Bread and Roses. Co-published by The Radical Education Profect, P.0. Box 561-A, Detro1t, Michigan, 48232, and Bay Area Radical Education Profect, 491 Guerrero St., San Franc1sco, Californ1a, 84110. F1rst published in Leviathan, 1969.

Reed, Evelyn. Problems of Women's Liberation: A Marxist Approach. New York: Mer1t Publishers, 1969.

We1ls, Lyn. American Women: The1r Use and Abuse. New England Free Press, 791 Tremont St., Boston, Massachusetts, 02118, 1969.

Worts, Rochelle, Ph. D. Ch1ld-Rearing And Women's Liberation. Paper presented at the Women's Weekend, Rusk1n College, Oxford Un1vers1ty, February 28, 1970. 
Sources Consulted, continued.

\section{Magaz1nes}

Collectively Edited. Women: A Journal of Llberation. Vo1. 1, No. 3, "Women In History", Spring, 1970. Vo1. 1, No. 4, "Women In Revolution", Summer, 1970. Vol. 2, No. 1, "Women In The Arts", Fall, 1970.

F1restone, Shulamith. Ed1tor. Notes From The Second Year: Women's Liberation. Radical Reminism, P.0. Box AA, Old Chelsea Station, New York, New York, 10011, 1970.

Transaction. Issue on the American woman. Vol. 8, No. 1/2. November/December, 1970.

\section{Articles}

Bowers, Faubion. "The Sexes: Getting It All Together." Saturday Review, January 9, 1971.

Grossman, Eudward. "In Pursult of The American Woman, or Gulliver At The Gynecologist's." Harper's Magazine, February, 1970 .

Maller, Norman. "The Prisoner of Sex." Harper's Magazine, March, 1971.

Newsweek Magazine. "Women's Ltb: The War On'Sex1sm'." March 23, 1970.

Stelnem, Glorla, "What It Would Be Like If Women Win." Time Magazine, August 31, 1970.

Time Magazine. "Who's Come A Long Way, Baby?" August 31, 1970. 
Sources Consulted, continued.

\section{Newspapers}

Come Out! A Liberation Forum For The Gay Commun1ty. New York Gay Liberation Front. Vol. 1, No. 5. New York: Gay Liberation Front, September/October, 1970.

Varlous 18sues of:

Aln't I A Woman? Iowa C1ty Publications Collective, Women's L1beration Front, P.0. Box 1169, Iowa C1ty, Iowa, 52240.

Everywoman. 6516 West 83rd St., Los Angeles, Callforn1a, 90045.

It Aln't Me Babe. Berkely: Women's Liberation Basement Press Collect1ve, 1126 Addison St., Berkely, Callfornia, 94702.

Off Our Backs. Off Our Backs, Inc., P.0. Box 4859, Cleveland Park Station, Washington, D.C., 20008.

Other

Kennedy, F1o. Symposium. Lew1s and Clark College. Portland, Oregon. October 14, 1970.

Rad1cal Therap1st, Inc. The Radical Therap1st: Speclal Issue On Women. Box 1215, Minot, North Dakota, 58701. August/September, 1970.

Steinem, Gloria. Symposium. Lew1s and Clark College. Portland, Oregon. October 14, 1970. 